\section{Managing Thyroid Cancer Without Thyroxine Withdrawal}

\begin{abstract}
Thyroxine (T4) withdrawal or recombinant TSH is used for the stimulation of thyroglobulin (Tg), whole-body scanning (WBS) and iodine-131 treatment in patients with thyroid carcinoma. This study evaluated the T4 dose reduction protocol as an alternative for patients' preparation. Fifty-one patients were submitted to total T4 withdrawal for WBS and Tg measurement. T4 treatment was then resumed and maintained until TSH reached levels $\leq 0.3 \mathrm{mlU} / \mathrm{l}$. The T4 dose was then decreased to $0.8 \mu \mathrm{g} / \mathrm{kg} /$ day and TSH was measured weekly. Tg was assayed when TSH was $>30 \mathrm{mlU} / \mathrm{l}$. Patients diagnosed with the disease upon initial evaluation were treated. We also evaluated the clinical and laboratory changes observed for both preparations. Using the reduced dose protocol, TSH levels $>30 \mathrm{mlU} / \mathrm{l}$ were reached within 6 and 8 weeks in 84.6 and $100 \%$ of the patients, respectively. T4 withdrawal was associated with more common symptoms of hypothyroidism and elevation of creatine kinase (CK) and LDL cholesterol. The T4 dose reduction protocol proved to be useful for Tg stimulation and ablative therapy, without the complication of severe hypothyroidism or the cost of recombinant TSH. (Arq Bras Endocrinol Metab 2006;50/1:91-96)
\end{abstract}

Keywords: Thyroid cancer; T4 dose reduction

\section{RESUMO}

Controlando o Câncer de Tireóide Sem Suspender a Tiroxina.

A suspensão da tiroxina (T4) ou o TSH recombinante são usados para a estimulação da tireoglobulina (Tg), para o mapeamento de corpo inteiro (MCl) e para o tratamento com ${ }^{131}$ lodo em pacientes com carcinoma tireoideano. Esse estudo avaliou um protocolo de redução de dose do T4 como alternativa para o preparo desses pacientes. Cinquenta e um pacientes submeteram-se à suspensão total de T4 para o $\mathrm{MCl}$ e a medida de Tg. Tratamento com T4 foi então reinstituído e mantido até que o TSH atingisse niveis $\leq 0.3 \mathrm{mUl} / \mathrm{l}$. A dose de T4 foi então dominuída para $0,8 \mathrm{\mu g} / \mathrm{kg} /$ dia e o TSH medido semanalmente. A Tg foi analisada quando O TSH estava > $30 \mathrm{mUl} / \mathrm{l}$. Pacientes diagnosticados com a doença na fase inicial da avaliação foram tratados. Nós também avaliamos as alterações clínicas e laboratoriais observadas para ambos os preparos. Usando o protocolo de redução de dose, níveis de TSH > 30 $\mathrm{mUl} / \mathrm{l}$ foram atingidos em 6 e 8 semanas em 84,6 and 100\% dos pacientes, respectivamente. A suspensão do T4 esteve associada com sintomas mais comuns de hipotireoidismo e com elevação da creatinoquinase (CK) e LDL-colesterol. O protocolo de redução da dose de T4 mostrou-se útil para a estimulação da Tg e terapia ablativa, sem apresentar as complicações do hipotireoidismo severo ou chegar ao custo do TSH recombinante. (Arq Bras Endocrinol Metab 2006;50/1:91-96)

Descritores: Câncer de tireóide; Redução da dose de T4 artigo original

\author{
Pedro Weslley S. do Rosávio \\ Flavio P.J. Vasconcelos \\ Ludmilla D. Cardoso \\ Márcio W. Lauria \\ Leonardo L. Rezende \\ Eduardo L. Padrão \\ Álvaro L. Barroso \\ Valéria C. Guimarães \\ Saulo Purisch
}

Department of Thyroid,
Endocrinology Service,
Santa Casa de
Belo Horizonte, $M G$.

Recebido em 14/04/04 Revisado em 22/09/04 e 15/10/04 Aceito em 15/12/05 
A FTER INITIAL THERAPY of differentiated thyroid carcinoma with thyroidectomy and ablation of remnants with iodine-131 (1-3), follow-up is generally carried out by serum thyroglobulin $(\mathrm{Tg})$ measurement alone in low risk patients (4) or combined with imaging methods in high-risk cases $(5,6)$. Despite its limitations, iodine whole-body scanning (WBS) is widely used to evaluate these patients $(7,8)$. Tg sensitivity is increased by TSH stimulation (9-11), as is the uptake of iodine-131 for diagnostic scanning or ablative therapy (12-15). In order to obtain satisfactory TSH levels, usually higher than $30 \mathrm{mU} / 1$, T4 therapy may be discontinued, rapidly inducing hypothyroidism (12-15), which can compromise the patients' quality of life and result, among other changes, in hypercholesterolemia and myopathy accompanied by a rise in creatine kinase (CK) (16-18). Recombinant TSH effectively stimulates $\mathrm{Tg}$ production and iodine uptake by tumor cells for WBS (11,19-21) without causing hypothyroidism. However, Pacini et al. (22) showed that hypothyroidism is more effective than recombinant TSH for ablative treatment. In addition to this lower efficacy in ablative therapy, the high cost of recombinant TSH is a restrictive factor for its routine use. Therefore, an alternative that does not present the symptoms caused by T4 withdrawal is required for follow-up tests in patients for whom recombinant TSH is not available. Guimarães \& DeGroot (23) have suggested an alternative protocol to increase TSH in which the thyroxine dose was reduced by half, reporting good results in terms of efficacy and reduction of morbidity. However, this method, which has always appealed a lot to us, has received some criticism (24). In the present study we reevaluated the dose reduction protocol compared to total T4 withdrawal, taking into account aspects such as efficiency in raising $\mathrm{TSH}$, symptoms, serum CK and LDL cholesterol levels, capacity to stimulate $\mathrm{Tg}$ production, and efficacy of ablative therapy.

\section{PATIENTS AND METHODS}

\section{Patient characteristics and study design}

Patients with differentiated thyroid carcinoma who had undergone total thyroidectomy followed by remnant ablation and who did not present distant metastases were evaluated 6 to 12 months after initial therapy. The patients were first prepared with T4 withdrawal for 5 weeks, receiving fixed doses of $50 \mu \mathrm{g} /$ day triiodothyronine (T3) for the first 2 weeks. The patients were then submitted to iodine WBS and Tg measurement during hypothyroidism. Antithyroglobulin antibodies $(\mathrm{TgAb})$ were not detected in any case. After evaluation, T4 treatment was resumed up to the point when TSH reached levels $\leq 0.3 \mathrm{mIU} / 1$, but still detectable, and maintained for 4 weeks. The T4 dose was then changed to $0.8 \mu \mathrm{g} / \mathrm{kg} /$ day (the difference between the calculated and administered dose varied from -6 to $+5 \mu \mathrm{g}$, average of $+2.3 \mu \mathrm{g}$ ) and serial measurements (weekly) of TSH were obtained. Patients were maintained on this preparation for a minimum of 6 and a maximum of 8 weeks. If during these evaluations ( 6 or 8 weeks) patients showed levels > 30 $\mathrm{mIU} / \mathrm{l}, \mathrm{Tg}$ was measured and patients whose initial evaluation indicated recurrence of the disease received a new dose of iodine-131 (100 mCi). In addition, we determined morbidity, preference for one of the two types of preparation, heart rate, CK, LDL cholesterol and free T4 during hypothyroidism, and the efficacy of ablative treatment in those patients submitted to the dose reduction protocol. Fifty-one patients, 43 women and 8 men, were studied. Age ranged from 19 to 56 years (mean of 38.6 years). Forty patients had papillary carcinoma and 11 had follicular carcinoma. Thirty-six patients were in stage I (tumor within the thyroid) and 15 were in stage II (metastases to the lymph nodes). A control group consisting of 24 patients who also had cervical disease after initial treatment and who had received the same $100-\mathrm{mCi}$ dose but were prepared with the classical protocol was retrospectively selected for comparison. All patients who were again treated with radioiodine showed cervical uptake $<3 \%$ (control WBS) and $\mathrm{Tg} \leq 20 \mathrm{ng} / \mathrm{ml}(\mathrm{TSH}$ $>30 \mathrm{mIU} / \mathrm{l})$.

The protocol was approved by the Research Ethics Committee of the institution and the patients gave informed consent to participate.

\section{Ig and TgAb measurements}

$\mathrm{Tg}$ was measured by an immunoradiometric assay (ELSA-hTG, CIS Bio International, France) with a functional sensitivity of $0.8 \mathrm{ng} / \mathrm{ml}$, with the reference value established by the laboratory ranging from 3 to $42 \mathrm{ng} / \mathrm{ml}$. TgAb were determined by a chemiluminescent assay (Chemiluminescent ICMA, Nichols Institute Diagnostics, San Juan Capistrano, CA) with a detection limit of $1 \mathrm{IU} / \mathrm{ml}$ and with a reference value $<2 \mathrm{IU} / \mathrm{ml}$. No TgAb were detected in these cases.

\section{CK, LDL cholesterol, TSH and free T4 measurements}

CK was measured by an enzyme assay, with a reference value of up to $165 \mathrm{U} / \mathrm{l}$ for women and up to $190 \mathrm{U} / \mathrm{l}$ 
for men. LDL cholesterol was determined by an enzyme colorimetric method, with a reference value of up to $160 \mathrm{mg} / \mathrm{dl}$. TSH was measured by an immunoradiometric assay (TSH MAIAclone, BioChem ImmunoSystems, Bologna, Italy), with a sensitivity of $0.03 \mathrm{mIU} / \mathrm{l}$ and the reference value established by the laboratory ranging from 0.3 to $4 \mathrm{mIU} / 1$. Free T4 was measured by radioimmunoassay (GammaCoat Free T4, Diasorin, Stillwater, Minnesota, USA), with a sensitivity of $0.08 \mathrm{ng} / \mathrm{dl}$ and a reference value ranging from 0.73 to $2.1 \mathrm{ng} / \mathrm{dl}$.

\section{Imaging methods}

Diagnostic WBS was performed with a tracer dose of $5 \mathrm{mCi}$ iodine-131 during hypothyroidism and administration of a low iodine diet during the 2 weeks preceding the exam. Anterior and posterior images of the whole body were obtained $72 \mathrm{~h}$ after iodine administration. Post-therapy WBS was performed 7 days after the administration of the ablative dose. Other imaging methods used for the definition of disease status were cervical ultrasound and contrast-free chest and mediastinum-computed tomography.

\section{Statistical methods}

Significance was determined by $\chi^{2}$ analysis and $\mathrm{p}$ values $<0.05$ were considered to be significant.

\section{RESULTS}

\section{Raising TSH}

Using the classical protocol, TSH levels $>30 \mathrm{mIU} / 1$ were reached in 78.4 and $100 \%$ of patients in the absence of thyroid hormone within 2 and 3 weeks, respectively. When TSH was $>30 \mathrm{mIU} / 1$, free $\mathrm{T} 4$ levels ranged from undetectable to $0.48 \mathrm{ng} / \mathrm{dl}$ (mean \pm SD: $0.21 \pm 0.23 \mathrm{ng} / \mathrm{dl}$ ), and TSH ranged from 53 to $186 \mathrm{mIU} / \mathrm{l}(83 \pm 23 \mathrm{mIU} / \mathrm{l})$. Using the reduced dose protocol, TSH levels $>30 \mathrm{mIU} / 1$ were reached within 6 weeks in $84.6 \%$ of patients and within 8 weeks in the remaining patients. A TSH value $>15 \mathrm{mIU} / 1$ was predictive of levels $\geq 25 \mathrm{mIU} / \mathrm{l}$ after 1 week. Basal TSH did not change among patients who successfully reached the required level within 6 and 8 weeks. When TSH was $>30 \mathrm{mIU} / \mathrm{l}(51.64 \pm 11.1 \mathrm{mIU} / \mathrm{l})$, free $\mathrm{T} 4$ ranged from 0.53 to $1.19 \mathrm{ng} / \mathrm{dl}(0.69 \pm 0.15 \mathrm{ng} / \mathrm{dl})$ (table 1). Figure 1 shows the weekly mean TSH values obtained with the T4 reduced dose protocol.

\section{Adverse effects}

\section{Symptoms}

Using the classical protocol, symptoms attributable to hypothyroidism (table 2) were observed in $70.6 \%$ of patients and $29.4 \%$ remained free of new complaints. With the reduced dose protocol, hypothyroidism symptoms were present in only $23.5 \%$ of cases, with most patients $(76.5 \%)$ being symptom-free (table 1$)$. When questioned about their preference, $35.3 \%$ of the patients reported no difference between the two types of preparation and $64.7 \%$ chose the reduced dose protocol. None of the patients preferred total T4 withdrawal.

\section{CK}

Basal CK levels were normal in all patients and the same concentrations were observed before application of the classical protocol and the reduced dose preparation $(90$ \pm 19 versus $94 \pm 17 \mathrm{U} / \mathrm{l}, \mathrm{p}=\mathrm{ns})$. After T4 withdrawal, $70.5 \%$ of the patients presented an increase in $\mathrm{CK}$ values (from 236 to $1,015 \mathrm{U} / 1$ ), an average of $364 \pm 168 \mathrm{U} / 1$ among the 51 patients and significantly higher than the $178 \pm 71 \mathrm{U} / 1$ found when the T4 dose was simply reduced. In this case, $80.3 \%$ of the patients showed normal levels of this enzyme (table 1 ).

\section{LDL cholesterol}

Basal LDL cholesterol levels were $<160 \mathrm{mg} \%$ in all patients, with no difference between values obtained before the classical protocol and the reduced dose preparation $(102 \pm 21 \mathrm{U} / \mathrm{l}$ versus $108 \pm 18 \mathrm{U} / \mathrm{l}, \mathrm{p}=\mathrm{ns})$. After T4 withdrawal, $62.7 \%$ of the patients showed val-

Table 1. Symptoms, heart rate, creatine kinase (CK), LDL cholesterol (LDL-C), TSH and free T4 obtained with the classical and dose reduction protocol.

\begin{tabular}{lccccccc}
\hline Preparation & $\begin{array}{c}\text { With } \\
\text { symptoms }\end{array}$ & $\begin{array}{c}\text { Without } \\
\text { symptoms }\end{array}$ & $\begin{array}{c}\text { Heart } \\
\text { rate }\end{array}$ & CK (U/l) & $\begin{array}{c}\text { LDL-c } \\
\text { (mg/dl) }\end{array}$ & $\begin{array}{c}\text { TSH } \\
\text { (mlU/l) }\end{array}$ & $\begin{array}{c}\text { Free T4 } \\
\text { (ng/dl) }\end{array}$ \\
\hline $\begin{array}{l}\text { Classical } \\
\text { protocol }\end{array}$ & $70.6 \%$ & $29.4 \%$ & $63 \pm 9$ & $\begin{array}{c}\text { Increased in } \\
70.5 \%: 364 \pm 168\end{array}$ & $\begin{array}{c}\text { Increased in } \\
62.7 \%: 172 \pm 22\end{array}$ & $83 \pm 23$ & $0.21 \pm 0.23$ \\
$\begin{array}{l}\text { Reduced } \\
\begin{array}{l}\text { dose } \\
\text { protocol } \\
\text { p-value }\end{array}\end{array}$ & $23.5 \%$ & $76.5 \%$ & $68 \pm 8$ & $\begin{array}{c}\text { Increased in } \\
19.7 \%: 178 \pm 71\end{array}$ & $\begin{array}{c}\text { Increased in } \\
29.4 \%: 138 \pm 18\end{array}$ & \pm 11.1 & $0.69 \pm 0.15$ \\
\hline
\end{tabular}




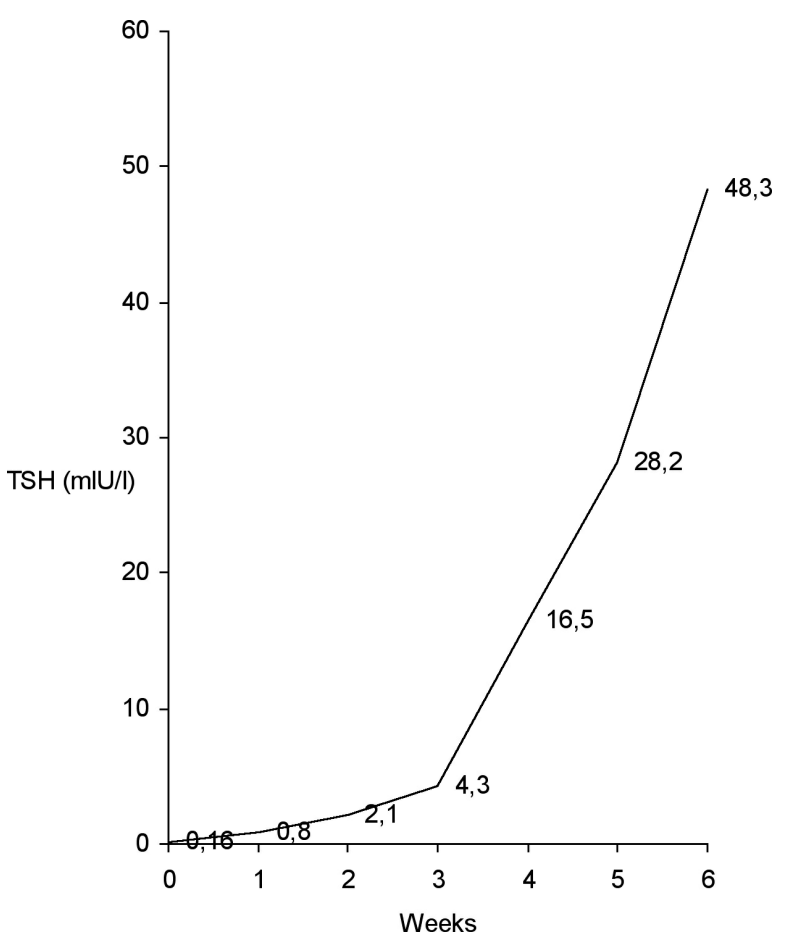

Figure 1. Weekly mean TSH levels obtained with the dose reduction protocol.

ues > $160 \mathrm{mg} \%$ ( 162 to $265 \mathrm{mg} / \mathrm{dl}$ ), with an average of $172 \pm 22 \mathrm{mg} / \mathrm{dl}$, a value significantly higher than the $138 \pm 18 \mathrm{mg} / \mathrm{dl}$ found when the T4 dose was simply reduced. In this case, $70.6 \%$ of the patients showed normal levels $(<160 \mathrm{mg} / \mathrm{dl})$ (table $\mathrm{l})$.

\section{Efficacy of ablative treatment with the reduced dose protocol}

Twenty patients showed recurrence of cervical remnants after initial therapy, all with $<3 \%$ uptake in the cervical bed (control WBS) and without distant metastases. These patients received a $100-\mathrm{mCi}$ dose after preparation with the reduced protocol and the success of the new therapy (negative WBS and $\mathrm{Tg}<2 \mathrm{ng} / \mathrm{ml}, 6$ months to 1 year after treatment) was $75 \%$. A group of 24 subjects prepared by total T4 withdrawal and showing the same characteristics (cervical recurrence, second treatment, cervical uptake $<3 \%$, dose of $100 \mathrm{mCi}$ ) was retrospectively selected for comparison among the patients seen at our institution. The efficacy of ablative therapy in this situation was $79.1 \%$, with no difference compared to the reduced dose preparation $(\mathrm{p}=\mathrm{ns})$.

\section{Efficacy of thyroglobulin generation}

No treatment was performed after Tg off T4 measurement until a new evaluation was done with the reduced dose protocol. Therefore, no change in the status of the disease was observed. Initial stimulated $\mathrm{Tg}$ was undetectable $(<\mathrm{lng} / \mathrm{ml})$ in 31 cases that were free of the disease and the same was observed for the $\mathrm{T} 4$ reduced dose preparation. Detectable Tg off T4 ranged from 2.4 to $20 \mathrm{ng} / \mathrm{ml}(8.87 \pm 6.05 \mathrm{ng} / \mathrm{ml})$ in patients with disease recurrence and from 1.8 to 18.3 $\mathrm{ng} / \mathrm{ml}(6.94 \pm 5.14 \mathrm{ng} / \mathrm{ml}, \mathrm{p}=\mathrm{ns})$ in reduced dose preparation.

\section{DISCUSSION AND CONCLUSIONS}

We considered a minimum TSH value of $30 \mathrm{mIU} / 1$ as ideal based on previous studies demonstrating an increase in iodine-131 uptake with these values (1215). Furthermore, exaggerated TSH rises have no additional benefits, as demonstrated by Goldman et al. (13), who did not detect any difference in uptake when employing median TSH levels of $68 \mathrm{mIU} / 1$ (2 week T3-off) versus $96 \mathrm{mIU} / 1$ (4 week T3-off). Using the reduced dose protocol, $84.3 \%$ of the patients reached these values within 6 weeks, demonstrating good efficacy. Basal TSH $(>0.03$ and $\leq 0.3 \mathrm{mIU} / \mathrm{l}$ ) was reduced in the present patients and no difference was observed between patients who reached the required TSH level within 6 or 8 weeks. Nevertheless, it is possible that the efficacy of this preparation is higher when TSH is $>0.3 \mathrm{mIU} / 1$ and lower if basal levels are undetectable. Values $>$ $15 \mathrm{mIU} / 1$ were predictive of TSH levels $>25 \mathrm{mIU} / 1$ after 1 week. These factors had already been defined by Guimarães \& DeGroot (23). In the present study we only evaluated patients who had undergone total thyroidectomy and ablative therapy, and therefore without functioning thyroid remnants which might have altered the efficacy of the protocol to raise TSH. In addition, none of the patients presented functioning metastases. We recognize that in the presence of large remnants or metastases this protocol may not be as successful, requiring longer preparation times.

Analysis of the symptoms observed in the present study clearly shows the advantage and patients' preference of treatment without T4 withdrawal, as also demonstrated by Guimarães \& DeGroot (23). In addition, laboratory parameters such as free $\mathrm{T} 4, \mathrm{CK}$ and LDL cholesterol significantly differed between the two protocols, in favor of the reduced dose protocol. Therefore, it is unquestionable that this preparation resulted in benefits in terms of quality of life and reduction of morbidity, in agreement with a previous study $(23)$. 
Table 2. Symptoms observed with the classical preparation and the reduced dose protocol.

\begin{tabular}{lccc}
\hline Symptoms & $\begin{array}{c}\text { Classical preparation } \\
\text { (patients with symptoms) }\end{array}$ & $\begin{array}{c}\text { Reduced dose protocol } \\
\text { (patients with symptoms) }\end{array}$ & p-value \\
\hline Dry or rough skin & 26 & 3 & $<0.01$ \\
Weight gain & 16 & 5 & $<0.05$ \\
Eyelid edema & 11 & 1 & $<0.01$ \\
Reduced work or usual & 28 & 6 & $<0.05$ \\
task performance & 24 & 6 & $<0.01$ \\
Constipation & 18 & 2 & $<0.01$ \\
Feeling cold & 12 & 3 & $<0.05$ \\
Depression & 34 & 9 & $<0.05$ \\
Fatigue & & & \\
\hline
\end{tabular}

Concerning iodine-131 uptake, Greenspan (24) has indicated the possibility that iodine-127, present in the thyroxine molecule, may compete with the tracer if T4 therapy is continued. In view of the small quantity of iodine-127 and considering the use of a reduced dose only and the prescribed low iodine diet, we do not believe that this fact may interfere. In addition, if there were interference, the use of recombinant TSH in patients on full $\mathrm{T} 4$ therapy would not be efficient to stimulate iodine uptake when performing WBS $(11,19-21)$. Despite the similar efficacy of the two preparations in remnant treatment with high iodine131 doses, the use of the reduced dose protocol for ablative therapy still requires caution and further studies because of the small size of the present series.

Additionally, we compared $\mathrm{Tg}$ measurement between the two preparations and observed that the reduced dose protocol is effective for $\mathrm{Tg}$ stimulation.

Another important aspect refers to the prolonged period of time under increased TSH, which could stimulate tumor growth more intensively than the classical protocol that results in fast TSH rises over a short period of time. Using the preparation without T4 withdrawal, increased TSH values were only observed in the last three weeks, showing that the delay is longer when starting from decreased TSH. In addition, the smaller concentrations compensate for the longer TSH exposure. Although we did not evaluate the TSH decrease after T4 treatment had been resumed, it is possible that the classical protocol delays normalization of TSH since the values obtained were higher.

After conclusion of this study, T3 was withdrawn from the Brazilian market due to some problems involving the company responsible for its manufacturing and distribution. Considering the high risk of an incorrect dosage during laboratory handling, we believe that the T4 dose reduction protocol is of greater importance in our country.

Weekly monitoring of TSH after complete T4 withdrawal can also be used, reducing the duration of hypothyroidism since the desired elevation of TSH can be rapidly achieved (average of 17 days) (25).

In conclusion, the dose reduction protocol is an especially effective alternative after total thyroidectomy and ablation of remnants and stimulates TSH for $\mathrm{Tg}$ measurement and possibly for WBS without the complication of severe hypothyroidism and the high cost of recombinant TSH. Concerning ablative therapy, we recommend caution and further studies including a larger number of patients.

\section{ACKNOWLEDGMENTS}

We thank Prof. Leslie J. DeGroot (University of Chicago) for his valuable contribution to the revision of this article.

\section{REFERENCES}

1. DeGroot LJ, Kaplan EL, McCormick M, Straus FH. Natural history, treatment, and course of papillary thyroid carcinoma. J Clin Endocrinol Metab 1990;71:414-24.

2. Mazzaferri EL, Jhiang SM. Long-term impact of initial surgical and medical therapy on papillary and follicular thyroid cancer. Am J Med 1994;97:418-28.

3. Schlumberger MJ. Medical progress - papillary and follicular thyroid carcinoma. N Engl J Med 1998;338:297306.

4. Mazzaferri EL, Robbins RJ, Spencer CA, Braverman LE, Pacini $F$, Wartofsky $L$, et al. A consensus report of the role of serum thyroglobulin as a monitoring method for lowrisk patients with papillary thyroid carcinoma. J Clin Endocrinol Metab 2003;88:1433-41.

5. Robbins RJ, Chon JT, Fleisher M, Larson SM, Tuttle RM. Is the serum thyroglobulin response to recombinant human thyrotropin sufficient, by self, to monitor for residual thyroid carcinoma? J Clin Endocrinol Metab 2002:87:3242-7.

6. Rosario PW, Maia FF, Cardoso LD, Fagundes TA, Reis JS, Purisch S. Usefulness of radioiodine scanning in patients with moderate/high risk differentiated thyroid carcino- 
ma in whom thyroglobulin (without thyroxine) is undetectable after initial treatment. Arq Bras Endocrinol Metabol 2004;48:384-8.

7. Grigsby P. Cost minimization analysis and utility of pretreatment and posttreatment total body iodine-131 scans in patients with thyroid carcinoma. Cancer 1998:82:931-5

8. Lind P. 131-I whole body scintigraphy in thyroid cancer patients. Q J Nucl Med 1999;43:188-94.

9. Ozata M, Suzuki S, Miyamoto T, Liu RT, Fierro-Renoy F, DeGroot LJ. Serum thyroglobulin in the follow-up of patients with treated differentiated thyroid cancer. J Clin Endocrinol Metab 1994:79:98-105.

10. Schlumberger M, Baudin E. Serum thyroglobulin determination in the follow-up of patients with differentiated thyroid carcinoma. Eur J Endocrinol 1998; 138:249-52.

11. Haugen BR, Pacini F, Reiners C, Schlumberger M, Ladenson PW, Sherman Sl, et al. A comparison of recombinant human thyrotropin and thyroid hormone withdrawal for the detection of thyroid remnant or cancer. J Clin Endocrinol Metab 1999:84:3877-85.

12. Maxon HR, Smith HS. Radioiodine-131 in the diagnostic and treatment of metastatic well differentiated thyroid cancer. Endocrinol Metab Clin North Am 1990;19:685717.

13. Goldman JM, Line BR, Aamodt RL, Robbins J. Influence of triiodothyronine withdrawal time on 1311 uptake postthyroidectomy for thyroid cancer. J Clin Endocrinol Metab 1980;50:734-9.

14. Edmonds CJ, Hayes S, Kermode JC, Thompson BD. Measurement of serum TSH and thyroid hormones in the management and treatment of thyroid carcinoma with radioiodine. Br J Radiol 1977;50:799.

15. Hilts SV, Hellman D, Anderson J, Woolfenden J, Van Antwerp J, Patton D. Serial TSH determination after T3 withdrawal or thyroidectomy in the therapy of thyroid carcinoma. J Nucl Med 1979;20:928.

16. Lien EA, Nedrebo BG, Varhaug JE, Nygard O, Aakvaag A, Ueland PM. Plasma total homocysteine levels during short-term iatrogenic hypothyroidism. J Clin Endocrinol Metab 2001;85:1049-53.

17. Weissel M, Kainz H, Hofer R. Changes in biochemical parameters during complete thyroid hormone deficiency of short duration in athyreotic patients. J Nucl Med 1986;27:1528-32.
18. Dubois A, Goldman JM. Gastric secretion and emptying in hypothyroidism. Dig Dis Sci 1984;29:407-10.

19. Giovanni V, Arianna LG, Antonio C, Francesco F, Michele K, Giovanni S, et al. The use of recombinant human TSH in the follow-up of differentiated thyroid cancer: experience from a large patient cohort in a single centre. Clin Endocrinol (Oxf) 2002;56:247-52.

20. Robbins RJ, Tuttle RM, Sharaf RN, Larson SM, Robbins HK Ghossein RA, et al. Preparation by recombinant human thyrotropin or thyroid hormone withdrawal are comparable for the detection of residual differentiated thyroid carcinoma. J Clin Endocrinol Metab 2001;86:619-25.

21. Durski JM, Weigel RJ, McDougall IR. Recombinant human thyrotropin (rhTSH) in the management of differentiated thyroid cancer. Nucl Med Commun 2001:21:521-8.

22. Pacini F, Molinaro E, Grazia Castagna M, Lippi F, Ceccarelli $C$, Agate $L$, et al. Ablation of thyroid residues with $30 \mathrm{mCi}$ 1311: a comparison in thyroid cancer patients prepared with recombinant human TSH or thyroid hormone withdrawal. J Clin Endocrinol Metab 2002;87:4063-8.

23. Guimarães V, DeGroot LJ. Moderate hypothyroidism in preparation for whole body 131 I scintiscans and thyroglobulin testing. Thyroid 1996;6:69-73.

24. Greespan FS. Moderate hypothyroidism in preparation for whole body 131 I scintiscans and thyroglobulin testing. Thyroid 1996;6:493

25. Liel Y. Preparation for radioactive iodine administration in differentiated thyroid cancer patients. Clin Endocrinol (Oxf) 2002;57:523-7

Endereço para correspondência:

Pedro Weslley Souza do Rosário

Centro de Estudos e Pesquisa

Clínica de Endocrinologia e Metabologia (CEPCEM)

Av. Francisco Sales 1111 , 5o andar, Ala D

30150-221 Belo Horizonte, MG

Fax: (31) 321-0836

E-mail: pedrorosario@globo.com 